\title{
Folketællinger i Nordslesvig 1864-1919
}

\author{
Af Hans $H$. Worsge.
}

Folketællingerne i hertugdømmet Slesvig fra tiden for 1864 er ligesom de tilsvarende tællinger i kongeriget udførligt behandlet af såvel statistikere som af personalhistorikere. ${ }^{1}$ I de almindelige håndbøger ${ }^{2}$ for personal- og slægtshistorikere kan man finde udmærkede og pålidelige oplysninger om, hvormeget der er bevaret af disse folketællinger. Med undtagelse af den forste folketælling, der afholdtes 1769, og som kun er bevaret fra enkelte områder, er det statistiske grundmateriale fra Nordslesvig i folketællingerne til og med 1860 godt bevaret. Dette materiale findes som bekendt hovedsagelig på Rigsarkivet, en ringere del på Gottorp — ret ukendt er det derimod, at Landsarkivet i Ảbenrå har mikrofilm af de på Rigsarkivet opbevarede folketællinger fra hele Sønderjylland og Holsten."

Anderledes sparsomt ligger det med oplysninger om materialet fra de folketællinger, der foretoges i Sønderjylland mellem 1864 og 1920. Vi vil i det følgende forsøge at råde bod herpå for Nordslesvigs vedkommende ved at meddele dels en oversigt over hvilke folketællinger, der fandt sted indenfor denne periode, og deres offentliggørelse, og dels en oversigt over, hvilket statistisk grundmateriale, der er bevaret og tilgængeligt fra disse tællinger, hvorimod der ikke vil blive gjort forsøg på at give en tolkning af materialet.

Da der ikke foreligger særbestemmelser, må man regne med samme tilgængelighedsregler som for de danske folketællinger $i$ tilsvarende periode, nemlig en løbende 50 års grænse for de personlige oplysningers vedkommende, medens talmaterialet fra hele perioden er tilgængeligt for såvel danske som tyske forskere.

Den sidste folketælling mellem krigene afholdtes i det danske monarki den 1. dec. 1860. Den næste ordinære folketælling skulle 
have været afholdt $\mathrm{i}$ hele monarkiet den 1 . febr. 1865, men medens denne tælling ved kongelig resolution af 18 . maj 1864 aflystes $i$ Danmark, gik man i de okkuperede landsdele den modsatte vej, idet den øverste civile myndighed i samråd med forbundskommissæren besluttede at rykke den frem og lade den afholde den 3 . dec. 1864. ${ }^{5}$ Tællingen blev i byerne ledet af magistraten, på landet af herredsfogeden. Tællingsskemaerne var de samme, som blev benyttet i 1860, blot lød rubrik 10 "Art des Aufenthalts am 3. Dezember, ob nur vorübergehend", medens den i 1860 var afsat til anmærkninger. Undtaget fra tællingen var personer, der opholdt sig som gæster på kroer el. lign. samt fremmede tropper. Denne folketælling afholdtes altså $i$ hovedsagen endnu efter de danske regler.

De folgende folketællinger, hvoraf den forste fandt sted 3. dec. $1867,{ }^{6}$ foregik efter prøjsisk mønster. Folketællingen var, hed det i bekendtgørelsen, et anliggende for den kongelige regering, afdl. indenrigsministeriet, og for de derunder direkte hørende kredsmyndigheder. Indenrigsministeriet organiserede tallingen gennem det kongelige prøjsiske statistiske bureau i Berlin. Udførelsen var de lokale myndigheders sag: på landet kommuneforstanderen evt. under opsyn af politimyndigheden, $i$ byerne magistraten og politiforvaltningen. I byer med mere end 5000 indbyggere skulle der nedsættes en tællingskommission, for de øvrige områder var detle frivilligt. De lokale myndigheder - resp. tællingskommissionen - skulle inddele kommunen i tællingsområder, i byerne af højst 100 husstande, på landet det halve. Endvidere skulle de udpege og instruere de såkaldte tællere - en for hvert område - hvis hverv vil blive skildret $i$ det følgende.

Alle i det prøjsiske landområde på tællingsdagen tilstedeværende personer skulle antegnes med oplysning om fulde navn, køn, fødested, fødselsdag og -år, stilling i familien, religion, hoved- og evt. bibeskæftigelse, statstilhørsforhold, færdighed $i$ at læse og skrive (besvares med ja eller nej), særlige handicap (blind, døvstum, åndssvag, vanvittig). Tællingen foregik husstandsvis, og gæster skulle desuden anføre deres sædvanlige bopæl. Hver husstand fik af tælleren udleveret et tællingsbrev ${ }^{7}$ med følgende indhold: et tællingskort pr. medlem af husstanden (kaldet $A$ ), hvor de ovenfor nævnte oplysninger skulle indføres; 
A.

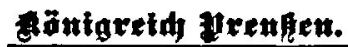

\section{Zुofksłälfuitg am 1. Dezember 1885.}

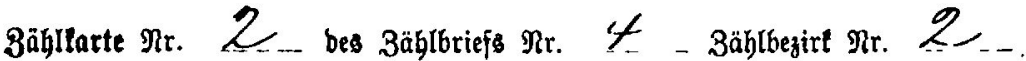

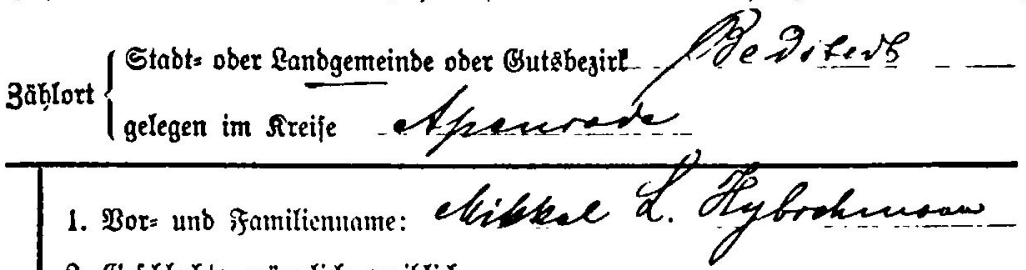

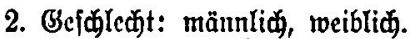

3. PIter: geboren ben

24. Zoobr _im Эahre 1849

4. Familientitund: Iebig (b. h. weter verlyeirutet ned verbeiratet genejen), verbeiratet, berwittuet, geichieben (auf Rebcužzeit geridtlid) getremt)

5. Geburţૂort:

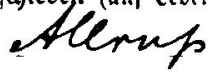
im ßreifi

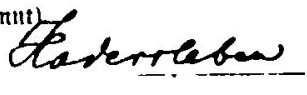

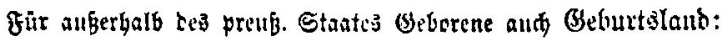

6. Religionșbelenntniß̄:

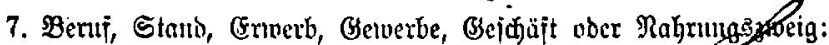

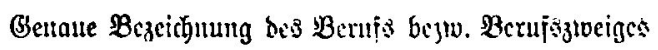

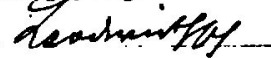

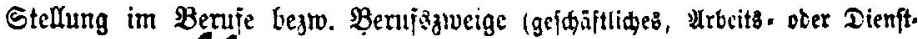
verb̧ảltni(日)

8. Staatsangehb̈rigleit:
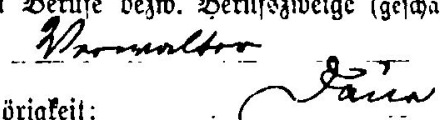

9. Steben Sie im altiven Sienjte bes jecres ober bcr Yharine?

Bharge:

Silupentigcil:

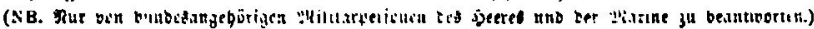

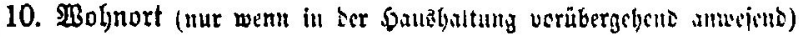

int Sreije (Etant, menn nidt im frelis. Etaate gelegen)

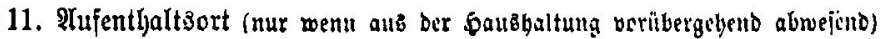

Forsiden af tallingskort A fra folketallingen 1885. Medens de ovrige kort af denne art er kasseret, findes tallingskortene fra 1885 for danske undersåtter på Rigsarkivet. 
B: fortegnelse over de $\mathrm{i}$ husstanden nærværende - her oplystes kun navnene og den familiære stilling; liste $\mathrm{C}$ : midlertidigt fraværende; $D$ : vejledning. Senest tre dage efter tællingsdagen skulle tællerne have indsamlet tællingsbrevene og udarbejdet en kontrolliste $(G)$, ved de senere folketællinger kaldet $F$, over indholdet af $B$ og C. Denne liste, der i det folgende vil blive omtalt som kontrolliste $\mathrm{F}$, indeholder kun navnene på husstandenes overhoveder, disses erhverv samt antallet af personer i husstanden. Hele materialet blev overgivet til de lokale myndigheder, der kontrollerede det og bekræftede det ved underskrift. Hvad der videre skulle ske, var forklaret $i$ "Vejledning for myndighederne" (E), medens tællernes arbejde var forklaret $i$ en særlig vejledning $(F$, senere også kaldet E). De lokale myndigheder udarbejdede en såkaldt "Ortsliste $(\mathrm{H})$ for hele kommunen, indeholdende følgende 9 rubrikker: 1. tallingsomrâdernes numre, 2 . disses navne, 3 . antal beboelseshuse, 4 . andre boliger, 5 . antal husstande, 6 . anstalter og kaserner, 7. tilstedeværende mandlig og 8 . kvindlig befolkning, 9. fraværende. Denne liste skulle hurtigst muligt sendes til landråden, der efter at have modtaget materialet fra hele kredsen, sammenfattede dette til en Ubersicht der allgemeinen Ergebnisse der Volkszählung " med de samme 9 rubrikker og de enkelte kommuneområder holdt for sig, ligeledes kaldet $\mathrm{H}$. Landråden lod derefter matcrialet gå videre til regeringen, der igen udarbejdede oversigter for hele regeringsområdet $(\mathrm{J})$ og indsendte disse til det $\mathrm{kgl}$. prøjsiske statitiske bureau i Berlin. Senest 20 dage efter tællingens afholdelse indsendtes til landråden skemaerne A, B, C og kontrolliste F, der fra 1880 skulle fremstilles $i$ to eksemplarer, hvoraf det ene skulle opbevares i kommunens arkiv. Landråden skulle derefter samle og indsende hele kredsens "urmateriale" til statistisk bureau i Berlin.

Ved de følgende folketællinger, der fandt sted 1. dec. 1871, $1875,1880,1885,1890$, (2. dec.) 1895,1905 og 1910 var fremgangsmåden $i$ store træk den samme. Følgende vigtigere forandringer fandt dog sted i spørgsmålene på skema $A$ : angivelse af handicap mangler 1875,1885 og 1890 . Fra 1875 er indføjet rubrikker vedr. militære tjenesteforhold, fra 1890 spørgsmål om modersmál og fra 1905 desuden spørgsmål, om man ved siden af modersmålet beherskede tysk. Spørgsmålet om analfabetisme 
bortfaldt fra og med tællingen 1875. Denne folketælling indtog iøvrigt en sæerstilling, idet den var kombineret med en "næringstælling ", hvor følgende sporgsmål blev stillet: hvilket erhverv driver De, i egenskab af a) selvstæendig, b) stedfortræder, c) overordnet, d) underordnet? Har De helårlig el. evt. halvårlig bibeskæftigelse?, i egenskab af a) selvstændig etc. Selvstændigt næringsdrivende skulle endvidere udfylde rubrikker om antal af ansatte og former for maskiner, og om disse blev drevet af dyre-, vand-, vind-, damp- eller gaskraft. Denne form fortsattes og udvidedes ved de såkaldte "Berufs- und Gewerbezählungen * af 5 . juni 1882,14 . juni 1895 og 12 . juni 1907 , som imidlertid falder udenfor rammerne af denne oversigt. Materialet fra disse tællinger er hevaret og offentliggjort i nogenlunde samme omfang som folketrellingsmaterialet.

De tre sidste folketællinger, der i tysk tid fandt sted i Nordslesvig, nemlig 1. dec. 1916, 5. dec. 1917 og 8 . okt. 1919, blev ligeledes foretaget gennem det statistiske bureau, men var af en noget simplere karakter. Tællingerne foregik husstandsvis, og hver hus stand fik en "Haushaltungsliste: (A), hvor samtlige tilstedeværende skulle anføres med: fulde navn, køn, fødselsdag og -år, familieforhold, statstilhørsforhold, erhverv, selvstændig eller ikke, virksomhedens art før krigen og nu, samt militære forhold. Endvidere skulle man oplyse, om man var krigsinvalid eller krigsfange. Tælleren skulle udregne resultatet for de enkelte husstande og indføre disse på tallerlisten $B$, hvorefter de lokale myndigheder skulle udfærdige kommunelisten C. Dette materiale videresendtes til landråden, der efter udfærdigelse af kredsliste $D$ sendte det hele ind til statistisk bureau. Liste $D$ indeholdt 1916 følgende rubrikker for hver kommune: tilstedeværende befolkning a) mænd, b) kvinder, heraf c) i aktiv tjeneste, d) krigsfanger. Fra 1917 havde liste $D$ også spørgsmål om antal husstande og midlertidigt fraværende. Som man vil se, var disse folketællinger $i$ høj grad præget af krigsforholdene.

Resultatet af folketællingerne 1916 og 1917 kan ikke uden videre tages for fuldt pålideligt $i$ alle enkeltheder. Det fremgår af de officielle bekendtgørelser, at man havde besluttet at lade afholde en ny folketælling den 4 . dec. 1918 for at fastslå den forsørgelsesberettigede befolknings faktiske antal, således at resul- 
tatet kunne tjene som grundlag for fordelingen af næringsmidlerne. ${ }^{8}$ Det hedder videre, at folketællingerne 1916 og 1917 ikke kan tjene som grundlag herfor, da der dels er kommet mange rettelser og tilføjelser til dem, og dels var afholdelsen af disse folketællinger generet af for sen udsendelse af papirerne og af kommunernes manglende vilje og evne! Folketællingen 4. dec. 1918 blev imidlertid aflyst, ${ }^{\circ}$ og først med tællingen 8. okt. 1919 fik man etableret et pålideligt grundlag for uddelingen af levnedsmiddelkort.

Hvor meget af dette store og værdifulde materiale fra perioden 1864-1919 er bevaret og tilgængeligt i dag? Først og fremmest har det prøjsiske statistiske bureau efter bearbejdelsen udgivet en del af resultaterne. ${ }^{10}$ Dette gælder dog ikke for folketællingen 1864, hvor der i 1866 i Slesvig blev udgivet et ret summarisk tabelværk, hvor den mindste enhed var købstad og herred." I den senere grundigere behandling af folketællingen 1864 , som det statistiske bureau i Berlin udgav, er Slesvig ikke medtaget. ${ }^{12}$ Resultatet af de følgende folketællinger til og med 1910 er publiceret $i$ serien "Preussische Statistik - Amtliches Quellenwerk $«{ }^{13}$ hvor kredsen, bykommunen og landkommunen med over 2000 indbyggere er de mindste enheder. Til gengæld er besvarelsen af samtlige spørgsmål bearbejdet og optaget i statistikken. Resultatet af folketællingerne 1916 og 1917 synes ikke at være offentliggjort. fra officiel side og 1919 kun meget fragmentarisk. ${ }^{14}$ Imidlertid findes der for folketællingerne $1871,{ }^{18} 1885,1895 \mathrm{og} 1905^{16}$ såkaldte »Gemeinde-Lexica «, der har den lille projsiske kommune som mindste enhed, ja, i noterne er der endog gjort rede for antal af huse og beboere $i$ de dele af kommunerne, der har særligt navn. Disse kommunale leksika er nærmest at betragte som udvidede optryk af "Ortsliste $\mathrm{H} \propto{ }^{17}{ }^{17}$

Hvad angår offentliggørelse af folketællingernes resultater i de lokale officielle organer "Kreisblätter", er det vanskeligt at se noget bestemt system. For Haderslev kreds synes kun resultatet af folketællingen 1910 offentliggjort i Kreisblatt. ${ }^{18}$ Resultatet er opstillet kommunevis med følgende rubrikker: antal beboelser, husholdninger, anstalter, antal mænd og antal kvinder. Denne form for offentliggørelse er desuden anvendt i folgende tilfælde: Abenrå $1895,1900,1905$ og 1910 og Sønderborg 1895, 1900, 1905 og 
1910 - her er dog også angivet antal af personer tilhørende de forskellige konfessioner. En anden og udførligere publikationsform er anvendt af Sønderborg kreds for folketællingerne 1875 og $1880 \mathrm{og}$ af Tønder kreds for 1880 , idet man her bruger samme system, som ved de kommunale leksika med de enkelte bebyggelser som mindste enhed. Til gengæld publicerer Tønder kreds ved de følgende folketællinger til og med 1905 kun de enkelte kommuners samlede indbyggertal. Det samme er tilfældet med 1885-tællingen i Åbenrå kreds. Hvis man imidlertid kun er interesseret i de enkelte kommuners samlede indbyggertal pr. folketællingerne $1867,1871,1875,1885$ og 1895, er disse lettere tilgængelige i de forskellige udgaver af Provinzialhandbuch Schleswig-Holstein. ${ }^{10}$

Vender vi os derefter til det bevarede arkivalske materiale, vil det vise sig, at dette $\mathrm{i}$ nogle tilfælde kan give supplerende oplysninger. Dette gælder desværre ikke folketællingen 1864, hvor hele materialet fra Slesvig - med undtagelse af enkelte lister fra Flensborg på Landesarchiv - synes at være gået tabt. ${ }^{20} \mathrm{Om}$ materialets skæbne har det ikke været muligt at få oplysninger, idet man hverken på Rigsarkivet eller på Landesarchiv synes at kende noget hertil. ${ }^{21}$ Ifølge mundtlige meddelelser fra tyske forskere skulle der dog være en chance for, at der på arkivet i Merseburg, DDR, skulle findes afskrifter af en del af materialet, men denne oplysning må tages med det største forbehold. ${ }^{22}$ For samtlige senere tællinger gælder det, at alt » urmaterialet ", der blev indsendt til statistisk bureau i Berlin efter statistisk udnyttelse er blevet tilintetgjort. ${ }^{23}$ Fra denne regel findes kun én undtagelse, nemlig tællingskortene (A) for danske undersåtter ved folketællingen 1885. Disse kort findes på Rigsarkivet. ${ }^{24}$

Vi må derfor holde os til de mere tilfældigt bevarede koncepter og genparter $\mathbf{i}$ den lokale administrations arkiver. Her gælder det for folketællingen 1867, at det dels må søges i amtsarkiverne, dels i landrådsarkiverne. ${ }^{25}$ I landrådsarkiverne kan fra de følgende tællinger indtil 1910 incl. $i$ alle tilfælde liste $H$ påregnes bevaret. Fra 1916 f. er det de knapt så fyldige lister D, der findes på Landsarkivet i Ảbenrå i landrådsarkiverne med følgende undtagelser: 1916 Åbenrå kreds, 1917 Sønderborg og Åbenrå kredse, 1919 Ảbenrå kreds. I enkelte tilfælde kan landrådsarkiverne rumme fyldigere materiale, således forefindes i Haderslev landråds- 
arkiv kontrolliste F 1910 for hele kredsen. ${ }^{26}$ Disse mere detaillerede lister, der giver navne på husfædrene og antal personer $i$ husstandene, skulle i flg. bestemmelserne fra 1880 findes i kommunernes arkiver, men det er desværre meget sjældent, at de gør det. I landkommunernes arkiver på Landsarkivet findes følgende materiale fra folketællingerne - hvis intet andet er anført, er det kontrolliste $\mathrm{F}$ :

Åbenrå amt: Felsted komm. 1880-1910, Gråsten 1890-1910, Rise 1880-1895, Rise-Hjarup 1900-1910, Tumbøl 1885-1910, 1916 (B).

Sønderborg amt: Broager komm. 1900, Egernsund 1917-1919 (B), Iller 1885-1895, Mølmark 1900, Pøl 1910, Skodsbøl 1880-1890, Ulkebøl 1871-1885.

Tønder amt: Drengsted komm. 1890-1905, Eggebæk 1890-1905, Sæd 1905, Terkelsbøl 1880-1905, Ubjerg 1900.

I de til Landsarkivet afleverede flækkearkiver findes kun fra Højer bevaret kontrolliste F fra årene 1895, 1900 og 1905.

For købstædernes vedkommende findes formentlig stadig en del kontrollister $\mathrm{F}$ blandt de ikke afleverede arkivalier. Herpå tyder, at der i Sønderborg byarkiv, der som det eneste er afleveret indtil 1920, ligger kontrollister $F$ bevaret fra $1880 \mathrm{ff}$.

Til supplement af dette materiale fra de officielle folketællinger findes der enkelte lister fra tællinger, der blev afholdt på kommunernes egen foranledning. Fra Haderslev købstad findes på folkeregistret i Haderslev mandtalslister 1910, 1912, 1915 og 1917 med opgivelse af samtlige indbyggeres fødselsdato og -sted, på folkeregistret i Ảbenrå findes tilsvarende lister fra $1885,1890,1895$, 1900,1905 og 1910. ${ }^{27}$ Fra Tønder findes intet, fra Sønderborg ejheller, men sidstnævnte sted findes det tyske meldekartotek intakt fra 1908, således at der kan skaffes oplysninger om alle personer bosat der siden 1908 - i Åbenrå er kartoteket intakt fra 1918. På Landsarkivet findes desuden særdeles velbevarede folketællingslister fra Christiansfeld 1885, 1890, 1895, 1900, 1905, 1910 og 1916 med samtlige indbyggere opført med angivelse af fødselsdag og sted. Fra Højer flække findes - desværre uden ang. af fødested indbyggerfortegnelser fra årene 1895 og 1905, og endelig haves en indbyggerfortegnelse for "Vestsiden af Vojens" ca. 1917-19 med angivelse af navn, stand, fødselsdag og -sted + statsborgerfor- 
hold. Til slut skal nævnes en »Hausliste zur Personenstandaufnahme" med tilsvarende oplysninger fra Sæd kommune udfærdiget 28. okt. 1907.

Der er således fra folketællingerne 1864-1919 fra Nordslesvig, især fra landdistrikterne, bevaret et forsvindende ringe materiale, der kan give oplysninger af personalhistorisk værdi, hvorimod materialet fra et statistisk og topografisk synspunkt vel stort set må karakteriseres som tilstrækkeligt.

\section{NOTER OG HENVISNINGER}

1. Litteraturhenvisninger se Joh. Hvidtfeldt: Håndbog for danske lokalhistorikere p. 151: Befolkningsstatistik.

2. Se f. eks. Alb. Fabritius og H. Hatt: Håndbog i slægtsforskning 3. udg. 1963 p. 150-154.

3. Se f. eks. Hans H. Worsøe: Grundbog i slægtshistorie (Viborg 1963) p. 36.

4. Oplysninger herom savnes selv i nyeste udgave af den under 2. nævnte bog. Det er heller ikke alm. kendt, at der findes alfab. register til Åbenrå købstads folketællingslister 1845 bảde på Ra. og La. Åb.

5. Verordnungsblatt für das Herzogthum Schleswig 1864, 5. nov. no. 125.

6. Verordnungsljlatt für Schleswig-Holstein 1867 no. 471.

7. Materialet er skildret på grundlag af vejledningen 1871 , men adskiller sig ikke væsentligt fra 1867 og de flg. tællinger.

8. Haderslev kredsblad 1918 stk. 889,30 . okt.

9. Smsts. stk. 916, 21. nov.

10. Ved denne summariske redegørelse må der gives afkald på henvisn. til sekundære værker med yderligere bearbejdelse af materialet.

11. Resultate der am 3. dec. 1864 stattgehabten Volkszählung im Herzogthum Schleswig. (Schleswig 1866).

12. Die Ergebnisse der Volkszählung und Volksbeschreibung, der Gebäude- und Viehzählung nach den Aufnahmen vom 3. Dez. 1864, bezw. Anfang 1865 und die Statistik der Bewegung der Bevölkerung in den Jahren 1862, 1863 und 1864. Preussische Statistik X.

13. Resultaterne af folketællingen 1867 er udg. i Preussische Statistik XVI, 1871 i XXX. Fra 1875 findes to sideløbende serier: "Die vorläufigen ..." og $\gg$ Die definitiven Ergebnisse der Volkszählung am .... alle $i$ ovennævnte serie.

14. Zeitschr. d. Preuss. statist. Landesamt 1921, p. 77 og Vierteljahrschrift zur Statistik des Deutschen Reichs 1920 hft. II p. 137 f.

15. Die Gemeinden und Gutsbezirke des Preuss. Stautes, VII SchleswigHolstein (Berlin 1874).

16. Gemeindelexicon für das Königreich Preussen auf Grund der Materialien der Volkszählung vom 1. Dez. 1885, VIII Schleswig-Holstein (Berlin 1888), dito vom 2. Dez. 1895 (1897), dito vom 1. Dez. 1905 (1908). 
17. Dette kan bedst illustreres med et tilfældigt valgt eksempel, Bedsted kommune (Åbenrå amt) 1871: Wohnplätze: 3, Wohngebäude 52, Haushaltungen a) einzel: 6, b) Familien: 60, Ortsanwesende Bevölkerung: männl.: 146, weibl.: 160, überhaupt: 306, davon ortsgebürtig: 136, am 3. Dez. 1867: 279. Preussen: 285, Nicht-Preussen: 21, Religion: a) evangelische: 306, b) Katholiken: o, c) sonstige Christen: o, d) Juden: o, Bekehrer etc.: o. Alter und Schulbildung: unter 10 Jahre: 61, über 10. J.: können lesen u. schreiben: 210, Analphabeten: 35, Blinde: o. Taube: o. Blödsinnige: o. Ortsabwesende: 2. Anmærkninger: Dorf Bedsted (Wohnhäuser u. Einwohnerzahl) 50-284, Wirtshaus Sivekro 1-11, Arndrupper Mühle 1-11. Og samme komm. 1905: Zahl der Wohnplätze: 5, Gesammtflächeninhalt: 1269,8 ha. Durchschnittlicher Grundsteuer Reinertrag auf 1. ha.: 9,86, bewohnte Wohnhäuser: 66, andere Baulichkeiten: $o$, gewöhnl. Haushaltungen: 64, einzellebende: 5. Ortsanwesende Bevölk: 334, davon männl. 158, aktive Militärpers.: 0 , evangelische 334, Katolische (etc. som 1871): o, Muttersprache: deutsch: 26, dänisch: 307, andere Sprachen: polnisch: 1. Kirchspiel Bedsted, Amtsbezirk: Hellewatt. Noter: Wohnstätte und Einwohner: Arendorf: 15-62, Arendorfmühle: 1-10, Bedstedfeld 6-20, Siverkrug 1-14.

18. Offentliggorelsen finder sted i Amtsblatt fra det følgende år.

19. sc. udgaverne fra $1871,1875,1880,1891$ og 1897.

20. Tællingslister fra Holsten og Lauenborg findes derimod på Landes. archiv, Gottorp, Abt. 412, no. 871-1226.

21. Rigsarkivet, j. nr. 1196/63. Landesarchiv Tagebuch 1269/63.

22. Landsarkivar Iversen har efter sit studiebesøg efteråret 1964 pả arkivet i Merseburg venligt meddelt, at der ikke synes at findes sảdanne af'skrifter dér.

23. Landesarchiv Tgb. 1241/63.

24. Sdj. Årb. 1942 p. 110 f. Se ogsá illustrationen p. 395.

25. Fra Åbenră amt f. eks. findes Ortsliste $H$ i amtsarkivet, journalsager 1868 no. 23, medens det tilsvarende materiale fra Sønderborg amt findes i landrâdsarkivet titel IV no. $111 \mathrm{f}$.

26. Hdsl. landrădsarkiv fag 156 no. 2.

27. For Hdsl.s vedkommende venligst meddelt af ekspsekr. Olav Christensen, for Åbenrå af overass. Holger Jacobsen, for de to andre kobstæder efter skriftlig henvendelse jan. 1964. 